\title{
KITAP INCELEMESi
}

\section{KALKINMA İKTISSADINI YENIDEN DÜŞÜNMEK}

Chang, Ha-Joon (2003), Kalkınma Reçetelerinin Gerçek Yüzü1 (Çev. Tuba Akıncılar) (İstanbul: İletişim Yayınları, 248 s.).

Chang, Ha-Joon ve Gabriel, Ilene (2005), Kalkınma Yeniden² (Çev. Emre Özçelik) (İstanbul: İmge Yayınevi, 283 s.).

Günümüz kalkınma politikalarına egemen olma iddiasındaki neo-liberalizm, iktisadi bir kavram olmanın ötesinde siyasi, ekonomik ve kültürel anlamları içinde barındırmaktadır. Bu özelliğiyle toplumsal yaşamın pek çok alanına etki edebilen neo-liberalizm, günümüzde IMF, Dünya Bankası ve Dünya Ticaret Örgütü gibi uluslararası örgütlerin öncülüğünde "başka seçenek yok" sloganıyla evrenselleştirilmeye çalışılmaktadır. Bu durum, neo-liberal politikaların dünyanın birçok yerinde dayatılması sorununu ortaya çıkarmaktadır. $\mathrm{Bu}$ süreçte, özellikle kalkınmakta olan ülkeler neo-liberal politikaların doğrudan etkisi altında kalmaktadırlar. Nitekim son yıllarda özelleştirme, serbest piyasanın oluşturulması, sermaye akışının serbestleştirilmesi, mali sistemin serbestleştirilmesi, ithalatın serbestleştirilmesi, ihracatın canlandırılması ve emek piyasasının esnekliği gibi pek çok uygulamanın bu ülkelerde hayata geçirilmesine tanıklık edilmektedir.

Ne ki, pek çok kalkınmakta olan ülke deneyimi bu politikaların yıkıcı sonuçlara neden olduklarını ortaya koymaktadır. Son yıllarda neo-liberalizmin siyasi, ekonomik ve kültürel hâkimiyetinden duyulan hoşnutsuzluk söz konusu yıkıcı politikaların bir sonucu olarak görülebilir. Bu bağlamda, Saad-Filho'nun (2007:16) dikkati çektiği üzere, küreselleşmeci neo-liberal projeye ve onun yıkıcı sonuçlarına karşı çıkmak kaçınılmaz görünmektedir. Ha-Joon Chang ve

1 Orijinal baskı için kaynakça: CHANG, Ha-Joon (2002), Kicking Away the Ledder: Development Strategy in Historical Perspective (London: Wimbledon Publishing Company, 187 p.).

2 Orijinal baskı için kaynakça: Ha-John CHANG / Ilene GRABEL (2004), Reclaiming Development: An Alternative Economic Policy Manual (London and New York: Zed Boks, 224 p.). 
Ilene Grabel'in aşağıda ele alınan çalışmaları bu mücadelede neo-liberalizmin rağbet gören politikalarını yanlışlaşmakta ve alternatiflerini sunmaktadırlar. Daha da önemlisi, yazarlar bu çalışmalarıyla kalkınma iktisadı üzerine yeniden düşünmemiz gerektiğini sağlamaktadırlar.

Kalkınma Reçetelerinin Gerçek Yüzü adlı kitapta ana tema, "korumac1lı" ve "serbestleştirme" kavramları etrafında yapılan bir tartışma üzerine inşa edilmektedir. "Zengin ülkeler gerçekten nasıl zenginleştiler?" sorusuna cevap arayan kitap, bugünün kalkınmış ülkelerinin (bundan sonra BKÜ), geçmişin kalkınmakta olan ülkeleriyken korumacı politikaları benimsediklerini/ uyguladıklarını ve kalkınmayı bu yolla sağladıklarını öne sürmektedir. Kitap ayrıca, günümüzde BKÜ'lerin, kendi tarihsel deneyimleriyle çelişmesine rağmen, kalkınmakta olan ülkelere neo-liberal politikaları dayattıkları üzerinde durmaktadir.

Kitabın sunduğu tarihsel malzeme, zaman dilimi olarak kabaca Napolyon Savaşları'nın (1815) sona ermesiyle Birinci Dünya Savaşı'nın başlaması (1914) arasındaki günümüz BKÜ’lerin çoğunun sanayi devrimlerini gerçekleştirdiği dönemi kapsamaktadır. Bu zaman dilimi içinde, Britanya (kitapta geçtiği adıyla), ABD, Almanya, Fransa, İsveç, Belçika, Hollanda, İsviçre, Japonya, Kore ve Tayvan gibi ülkelerin politika ve kurumlarına bakılmaktadır.

Koreli yazar Ha-Joon Chang, bu kitabinda, Alman Tarihselci Okulun somut ve tümevarımcı yöntemini benimseyerek, kalkınma iktisadı açısından BKÜ'lerin (belirtilen zaman dilimi içindeki) politika ve kurumları üzerine etraflıca bir tartışma yapmaktadır. Yazar, benimsediği somut, tümevarımcı ve tarihsel metodolojik yaklaşımın önemini şu ifadelerle açıklamaktadır:

"Bu yaklaşım, doğru uygulandığında, kendiliğinden bir model ortaya çıkacağı umuduyla tarihsel gerçeklerin toplanması ve kataloglanmasıyla sınırlı değildir. Daha ziyade bu yaklaşım, devamlılık arz eden tarihsel bir model arayışını, bu modelleri açıklayan kuramların yapılandırılmasını ve teknolojik, kurumsal ve siyasi koşullardaki değişiklikler de göz önüne katılarak bu kuramların güncel sorunlara uygulanmasını içerir" (s, 22).

Chang'e göre, kalkınma iktisadının en parlak dönemi olan 1960'larda, BKÜ'lerin tarihsel deneyimlerinden kalkınmakta olan ülkeler adına ders çıkarılması amacıyla derlemeler yayınlanmaktaydı. Ancak son birkaç on yılda, tarihselci yaklaşımın iki iktisat alt alanı olan "kalkınma iktisadı" ve "iktisat tarihi" tümevarımsal usavurmayı reddeden neo-klasik iktisadın egemenliğine girmiştir. Bunun bir sonucu olarak günümüzde iktisadi kalkınma politikası tartışmaları tarih dışı bir hal almıştır.

“...ne yazık ki, birkaç dikkate değer istisna dışında geçtiğimiz birkaç on yılda iktisadi kalkınma alanında tarihsel yaklaşımı benimseyen çok az 
sayıda çalışma yapılmıştır. Bu nedenle, bu kitabın amaçlarından biri, tarihsel yaklaşımı günümüzün popüler söylemlerinden olan "doğru politikalar" ve "iyi yönetişim"in eleştirisine uygulayarak bu yaklaşımın ne kadar yararlı olduğunu bir kez daha doğrulamaktır" $(\mathrm{s}, 26)$.

Tam da bu gerekçeyle, kitapta günümüz iktisat alanına egemen olan neo-klasik yaklaşım (ve onun soyut ve tümdengelimci yöntemi) eleştirilerek, somut ve tümdengelimci yöntem temelinde, tarihselci bir yöntem benimsenmektedir denilebilir.

Kalkınma Reçetelerinin Gerçek Yüzü dört bölümden oluşmaktadır. Giriş niteliği taşıyan Birinci Bölüm, çoklu güç ilişkileri temelinde şekillenen günümüz küresel ekonomik sistemin kalkınmakta olan ülkelere dayattığ 1 politikaların eleştirisiyle başlar:

"Halen, kalkınmakta olan ülkeler üzerinde bir dizi 'doğru politika' ve 'doğru kurum'u benimsemeleri yönünde, kalkınmış ülkeler ve onların denetlediği uluslararası kalkınma politikası kurumları tarafından uygulanan büyük bir baskı vardır. Buna göre, 'doğru politikalar' genel olarak Washington Uzlaşması tarafindan önerilenlerdir. Bunlar, daraltıcı makroekonomik politikaları, uluslararası ticaret ve yatırımın serbestleştirilmesini, özelleştirmeyi ve deregülasyonu (kuralsızlaştırma) içeririler. 'Doğru kurumlar' ise temel olarak kalkınmış ülkelerde, özellikle de Anglo-Amerikan ülkelerinde bulunanlardır. En önemlileri, demokrasi, 'iyi' bir bürokrasi, bağımsız bir yargı, fikri mülkiyet hakları da dâhil olmak üzere güçlü bir şekilde korunan mülkiyet hakları, şeffaf ve piyasaya yönelik kurumsal yönetişim (corporate governance) ve siyasetten bağımsız bir merkez bankası dâhil olmak üzere finans kurumlarıdır" (s, 15).

Dikkat edilirse yazar, politika ve kurum arasında bir ayrıma gitmektedir. Kitapta serbestleştirme, özelleştirme, dergülasyon gibi kavramlar politika başlığ1 altında incelenirken, demokrasi, bürokrasi, yargl, fikri mülkiyet gibi kavramlar kurum başlı̆̆ altında ele alınmaktadır.

Bu kapsamda, kitabın İkinci Bölüm'ü politika başlı̆ğ altında, temel olarak sanayi, ticaret ve teknoloji politikalarını (kısaca STT politikaları) konu edinmektedir. Bu bölümün kilit kavramı önemli bir STT politikası olarak ele alınan "bebek sanayi koruması"dır. Yazar bu bölüme, bir önceki bölümde göndermede bulunduğu Washington Uzlaşması ve bu uzlaşmanın öngördüğü politika tavsiyelerinin altını çizen neo-liberal esaslı bir hikâye anlatarak başlamaktadır.

Hikâyeye göre, on sekizinci yüzylldan itibaren laissez faire'ci Britanya'nın sınaî başarısı serbest-piyasa ve serbest-ticaret politikalarının doğru politikalar 
olduklarını kanıtlamaktadır. Britanya'nın başarısı, diğer ülkelerin merkantilist politikaların sınırlarını fark etmelerini ve 1860 'larda serbest ticaret ilkelerini benimsemelerini sağlamıştır $(s, 33,34)$. Böylece on dokuzuncu yüzyılda mükemmelliğe ulaşan liberal dünya düzeni daha önce görülmemiş bir zenginleşme döneminin yaşanmasını beraberinde getirmiş̧ir. Bu süreçte Birinci Dünya Savaşı'nın yaşanmış olması bir talihsizliktir. Zira dünya ekonomik ve siyasal sisteminin istikrarsiz bir hale gelmesiyle birlikte, ülkeler ticarete engeller koymaya başlamışlardır (s, 35).

Hikâyeye göre, İkinci Dünya Savaşı'ndan sonra GATT görüşmelerinin başlamasıyla birlikte ticareti serbestleştirmede önemli aşamalar kaydedildi. Ancak, kalkınmış ülkelerde 1970'lere kadar, kalkınmakta olan ülkelerde 1980'lerin başına kadar iktisat yönetiminde korumacı yaklaşımlar egemen oldu. Ancak bu politikalar; laissez faire politikaları ve uluslararası açıklığı vurgulayan neo-liberalizmin 1980'lerdeki yükselişiyle birlikte tüm dünyada büyük oranda terk edildi. Sonuç olarak, kalkınmakta olan ülkelerin çoğu neoliberal politika reformlarına kucak açtılar (s, 35,36).

Nitekim 1980'lerden sonra korumacılıktan neo-liberal politikalara doğru kayış1 simgeleyen üç örnek verilebilir. Bunlar sırasıyla, Brezilya'nın 1980'lere kadar önde gelen bağımlılık kuramcısı olan Fernando Henrique Cardosu'nun başkanlığında neo-liberal doktrini benimsemesi; ABD karşıtı Meksika'nın NAFTA $^{3}$ 'ya girmesi; bir zamanlar korumacıllğın ve düzenlemelerin kalesi olan Hindistan'ın açık, liberal ekonomiye yönelmesidir (s, 37).

Neo-liberal politikaları taçlandıran olay ise, 1989'da komünizmin çöküşüdür. $\mathrm{Bu}$ sürecin devamı olarak, DTÖ gibi yeni küresel kurumsal yönetişim kurumlarının oluşturulmasıyla beraber, günümüzde politika değişiklikleri, refah potansiyeli bakımından ancak liberalizmin daha önceki 'Altın Çağı'yla (18701914) karşılaştırılabilecek yeni bir küresel iktisadi sistemin ortaya çıkmasını sağlamıştır (s, 37).

Chang'a göre hikâye böyle anlatıldığında etkileyici bir resim çıkar ortaya çıkmaktadır. Ancak hikâye yanıltıcıdır. On dokuzuncu yüzyılda Britanya'ya bakılarak bir laissez faire döneminin yaşandığı söylenebilir ancak on sekizinci yüzyılda Britanya'da korumacı politikalar yoğun olarak uygulanmıştı ve on dokuzuncu yüzyıl, on sekizinci yüzyılın içinden çıkmıştı. Dolayısıyla, on dokuzuncu yüzyılda Britanya örneğine bakılarak onun sınaî başarısına bir neden aranacaksa bu, serbest-piyasa ve serbest-ticaret politikaların aksine on sekizinci yüzyılda uygulanan korumacı politikalardır.

3 The North American Free Trade Agreement -Kuzey Amerika Serbest Ticaret Anlaşması 
Benzer bir durum ABD örneği için de geçerlidir. Chang, ABD'de serbest ticaret karşıtı düzenlemelerin II. Dünya Savaşı'na kadar devam ettiğini, ancak savaş sonrasında ABD'nin sanayi alanındaki üstünlüğünü kurmasıyla birlikte ticareti serbestleştirdiğini, dahası serbest ticaretin en ateşli savunucusu haline geldiğini belirtir. Chang, II. Dünya Savaşı öncesinde, ABD'nin hemen hemen bütün sektörleri kapsayan gizli korumacı önlemler konusunda bütün ülkelerden daha saldırgan davrandığını dile getirmektedir. Bu önlemler arasında gönüllü ihracat kisitlamaları (voluntary export restrains), teksitl ve giyimde kotalar, tarım ürünlerinde kotalar ve teşvik, tek taraflı ticaret yaptırımları yer almaktadır. Her ne kadar yazar, ABD'nin günümüzde serbest ticaretin en ateşli savunucusu haline geldiğini belirtse de, bu politikayı kendisi için her zaman uygulamadığını belirtmek gerekir. Nitekim günümüz ABD politikalarını Yeni Emperyalizm adlı kitabında değerlendiren David Harvey $(2008: 63,111)$, ABD'nin DTÖ'nün serbest ticaret anlaşmalarına (GATT ${ }^{4}$, GATS $^{5}$ vb.) uyum göstermediğini, anlaşmaların kurallarına aykırı davrandığını belirtmektedir.

Chang, korumacı politikaların paralel bir zaman diliminde Almanya, Fransa, İsveç, Belçika, Hollanda, İsviçre gibi ülkelerde de uygulandığını söylemektedir. Ancak söz konusu ülke örneklerini kitapta ayrı ayrı incelediğimizde (yazar her bir ülke için ayrıntılı örnekler vermektedir) bu ülkelerde, ABD'de olduğu gibi bütün sektörleri kapsayan bir korumacıllk yerine, bazı anahtar sektörlerin yoğun bir biçimde korunduğu "odaklanmış tarife korumas"1 politikasının tercih edildiğini görmekteyiz.

Korumacı politikalar açısından kitapta verilen örnek ülkeler arasında Asya ülkelerindeki gelişmeler dikkat çekicidir. Yazar, örnek ülke olarak Doğu Asya ülkesi olan Japonya üzerinde durmaktadır. Kitapta, on dokuzuncu yüzyılın ikinci yarsından sonra, modernleşme rejimi altında, Japon devletinin ülkenin kalkınmasında önemli bir rol üstlendiğine dikkat çekilmektedir. Bazı sanayi kollarında devlete ait örnek fabrikaların kurulması, ulaşım altyapısı temelindeki geniş ölçekli projelere devletin katkısı, devletin gelişmiş yabancı teknolojilerin ve kurumların aktarılmasına yönelik politikaları hayata geçirmesi, ayrıca BKÜ’lerden sınaî kalkınma için gerekli olduğuna inanılan kurumların ithal edilmesi, devletin etkisine örneklerden bazılarıdır. Japonya'daki korumacı politikaların, ABD'den farklı olarak, diğer kalkınmış ülkeler gibi odaklanmış tarife koruma politikasıyla benzerlikler gösterdiğini söyleyen yazar, bu tür

4 The General Agreement on Tariffs and Trade - Gümrük Tarifeleri ve Ticaret Genel Anlaşması

5 The General Agreement for Trade in Services - Hizmet Ticareti Genel Anlaşması 
politikaların Japonya'nın kalkınmasında önemli bir rol oynadığı üzerinde durmaktadir (s, 89-94).

Yazar, II. Dünya Savaşı'nın neden olduğu çöküntü sonrası, Japonya'nın büyüme hızının artarak devam ettiğini farklı veriler temelinde ortaya koyduktan sonra, özelde Japonya'da, genelde ise Asya'nın yeni sanayileşen ülkelerinde, kalkınmanın/büyümenin hayret verici düzeylerde seyretmesinin temel nedeninin devlet tarafindan uygulanan etkin STT politikaları olduğunu söyleyerek genel bir sonuca ulaşmaktadır (s, 95).

$\mathrm{Bu}$ bölümün bir diğer dikkat çekici konusu, kalkınmış ülkelerin, kalkınma aşamalarında sömürgelerine uyguladıkları politikalardır. Bu konuda özellikle Britanya'nın ABD üzerindeki politikaları üzerine verilen örnekler ilgi çekicidir. Genel olarak sömürgelerde sanayinin gelişmesini önlemeye dönük olan söz konusu politikalar, BKÜ’lerin günümüz kalkınmakta olan ülkelerle olan ilişkileriyle paralellik göstermesi bakımından üzerinde düşünmeye değer görünmektedir (s, 97-100).

Yazarın bütün bu örnek ülkeler temelinde yaptığı değerlendirmelerle dikkati çekmeye çalıştığı nokta, ister kapsayıcı koruma politikaları olsun, isterse belli sektörlere uygulanan koruma politikaları olsun, BKÜ'lerin büyümeyi sağlamada korumacı politikaları benimsedikleri gerçeğidir. $\mathrm{Bu}$ anlamda, BKÜ'ler günümüzde her ne kadar neo-liberal politikaları benimseseler ve bunu kalkınmakta olan ülkelere dayatsalar da, kalkınma aşamalarında korumacı politikaları uygulamada son derece gayretkeş oldukları belirtilmektedir:

"BKÜ’ler (bugünün kalkınmış ülkeleri), yakalama (kalkınma) dönemindeyken bebek sanayilerini korudular, gelişmiş ülkelerdeki kalifiye işçileri ayarttılar ve makineleri kaçırdılar, sanayi casusluğu yaptılar, patentleri ve ticari marka haklarını ihlal ettiler. Ancak kalkınmış ülkeler grubuna katıldıkları andan itibaren serbest ticaret savunuculuğu yaptılar, kalifiye işçilerin ve teknolojilerin çıkışını engellediler; patent ve ticari marka haklarının güçlü koruyucuları oldular" (s, 117).

Yazar bu bölümde ayrıca BKÜ’lerin uygulamış oldukları STT politikalarıyla bugünün kalkınmakta olan ülkelerinin uygulamakta oldukları STT politikalarını karşılaştırmakta ve "verimlilik farkı" göz önüne alındığında, bugünün kalkınmakta olan ülkelerinin BKÜ'lerden çok daha az korumacı oldukları sonucuna varmaktadır.

Kitabın Üçüncü Bölüm'ü kurumlar ve ekonomik büyüme konusuna ayrılmaktadır. Hatırlanacağı üzere, yukarıda yazarın politika ve kurum arasında bir ayrıma gittiğinden söz edilmişti. İkinci bölüm tarihsel bir perspektiften "doğru" diye nitelenen politikaların gelişimini incelerken, bu bölüm yine aynı zaman dilimi içinde BKÜ’lerin kurumsal gelişme sürecini konu edinmektedir. 
$\mathrm{Bu}$ bölümün kilit kavramı son yılların moda sloganı haline gelen "iyi yönetişim"dir. Yazar, iyi yönetişim yapısının ayrılmaz parçası olarak görülen çeşitli kurumların, BKÜ'lerde on dokuzuncu ve yirminci yüzyıllarda (kendileri kalkınmakta olan ülkeler iken) nasıl ortaya çıktıklarını incelemektedir. Altı kurumsal gelişme alanı incelenmektedir. Bunlar sırasıyla, "demokrasi", "bürokrasi ve yarg1", "mülkiyet hakları rejimi", "kurumsal yönetişim", "finans kurumları" ve "sosyal refah ve işgücü" kurumlarıdır.

Son dönem uluslararası kurum ve kuruluşların raporlarında sıklıkla geçmeye başlayan iyi yönetişim kavramı, bu bölümde kalkınma politikaları tartı̧̧malarının merkezinde yer almaya başlaması nedeniyle ele alınmaktadır. Yazara göre, son on yılda kalkınma politikalarına yön veren uluslararası kurumlar, kalkınma ve kurumsal yapı arasında doğrudan bağlantı kurmaya başladılar.

"Özellikle zayıf kurumların bir sonucu olduğu düşünülen son Asya krizinden sonra, kalkınma politikalarına yön veren uluslararası kurumlar bu kez "doğru kurumların" (...) "yönetişimle ilgili şartll1ıklar" önemini vurgulamaya başladı" (s, 125).

$\mathrm{Bu}$ kapsamda, her bir kurum kitapta ayrıntılı olarak analiz edilmektedir. $\mathrm{Bu}$ bölümde de, (İkinci Bölüm'de olduğu gibi) benzer BKÜ'lerdeki kurumsal gelişmenin evrim sürecine bakılmaktadır. Toparlayıcı olması açısından, BKÜ'lerdeki kurumsal gelişme süreci üç başlık altında toplanabilir.

1. 1820-Erken dönem sanayileşme

2. 1875-Bütün hızıyla sanayileşme

3. 1913-Sınaî olgunluğun başlangıc1

Yazar, belirtilen üç zaman dilimi içerisinde BKÜ'lerin kalkınma aşamalarındayken kurumsal gelişme açısından son derece geri durumda olduklarını söylemektedir. Kitapta verilen bilgilere göre, örneğin 1820'de hiçbir BKÜ'de oy hakkı toplumun geneline yayılmış değildi. Modern anlamda bürokrasi bulunmamaktaydı. ABD gibi ülkelerde mülkiyet hakları rutin olarak ihlal ediliyordu. Sadece bir avuç ülkede patent yasası bulunmaktaydı. Modern şirketlerin gelişmesinde çok önemli bir rol oynayan sınırlı sorumluluk, hiçbir ülkede yaygın değildi. İflas yasası olan ülkelerde bile bu yasalar eksikti ve sadece bir grup işadamına uygulanmaktaydı. Rekabet yasası, (Fransa dışında) hiçbir ülkede bulunmuyordu. İtalya'nın belli bölgeleri ve ABD dışında bankalar ortaya çıkmamıştı. BKÜ'lerin hiç birinde banknot basma tekeline sahip ve resmen "son borç verici merci" görevi gören bir merkez bankası bulunmamaktaydı. Az sayıda ülkede menkul kıymetler piyasası düzenlenmekteydi. Gelir vergisi ancak savaş zamanı bir acil durum önlemi olarak kullanılıyordu. Yine BKÜ'lerin hiçbirinde sosyal refah kurumları veya 
çalışma saatlerini, çocuk işgücünü, işyeri güvenliğini veya çalışma koşullarını düzenleyen kurumlar bulunmaktaydı.

Yazar, 1875'e gelindiğinde sanayileşme süreciyle birlikte BKÜ'lerin kurumsal gelişme alanında ciddi ilerlemeler kaydettiklerini belirtir. Ancak ona göre, bu ülkelerin eriştikleri düzey, bugün benzer kalkınmışlık düzeyinde olan ülkelerden talep edilen düzeyin altında kalmaktaydı. Buna paralele olarak, 1913'te BKÜ'lerin en zengin olanları, bugün kalkınmakta olan ülkeler arasında en iyi durumda olanların (Brezilya, Tayland, Türkiye vb.) düzeyindeydiler fakat bu ülkelerdeki kurumların standardı bugün bu ülkelerden talep edilen "dünya standartları"nın altındaydı.

Tüm bu veriler 1şığında yazarın bu bölümde vardığı sonuçlardan biri, günümüz kalkınmakta olan ülkelerin kurumsal kalkınma düzeyinin, BKÜ’lerin benzer kalkınmışlık düzeyindeyken sahip oldukları kurumsal gelişme düzeyinin çok üzerinde olduğudur. Ona göre, aynı kalkınmışlık düzeyindeki bugünün kalkınmakta olan ülkeleriyle karşılaştırıldığında BKÜ'lerin önde oldukları tek alan, 1880'lerden itibaren büyük ilerleme göstermiş olan sosyal refah kurumlarıydı. 1913'te birçok BKÜ'de (tamamlanmamış olsa da) sanayi kazası sigortası, sağlık sigortası, kamu emeklilik kurumları bulunmaktaydı. İşsizlik sigortası ise henüz çok yeniydi. Yazarın çıkardığ 1 bir diğer sonuç, BKÜ’lerde kurumsal gelişmenin, kurumlara olan gereksinimin ortaya çıkmasından, yüzyıllar değilse bile, on yıllar sonra mümkün olabildiğidir. Yazara göre tam da bu nedenle, kalkınmakta olan ülkelerden 5 ila 10 yıl gibi kısa süre içinde "dünya standartlarında" kurumlar talep edilmesinin, bu talep gerçekleşmediğinde bu ülkelerin cezalandırılmasının, bu taleplerde bulunan BKÜ'lerin kendi tarihsel deneyimleriyle çelişmektedir.

Sonuç yerine yazılan kitabın Dördüncü Bölüm'ünde yazar, belli başlı sonuçlara ulaşmaktadır. Yazar öncelikle, BKÜ'lerde benimsenen politikaların ve kurumların bugün, kalkınmakta olan ülkelere tavsiye edilen ve hatta onlardan talep edilen kurumlardan farklı olduğu ve bu ülkelerin kalkınmakta iken benimsediklerinden farklı olduğu şeklinde genel bir değerlendirmede bulunmaktadır (s, 207). Bu bağlamda, kalkınmaya yönelik iktisadi politikalar açısından BKÜ'lerin bebek sanayilerini teşvik etmeye yönelik olarak müdahaleci STT politikaları uyguladıklarını, dolayısıyla, kalkınma aşamalarındayken bugünün kalkınmakta olan ülkelerinden daha fazla korumacı olduklarına dikkat çekmektedir (s, 210). Yazar'a göre, günümüzde tavsiye edilmekte olan ve serbest ticaretin ve laissez faire'ci STT politikalarının faydalarını öne çıkaran "doğru" politika paketi tarihsel deneyimlere ters düşmektedir. BKÜ'lerin bugün bulundukları yerde olmalarını sağlayan politikalar, yani etkin STT politikaları, tam da bugün kalkınmakta olan ülkelere asla uygulamamaları gerektiğini, ekonomik kalkınmaya zararlı olduğunu 
söyledikleri politikalardır. Dolayısıyla, BKÜ'ler, başarılarının sırlarını saklamaktadırlar; dahası, kalkınmakta olan ülkelerin de tırmanmasını engellemek için başarının merdivenini itmektedirler.

Yazar ayrıca, neo-liberal politika reformlarının vaat ettiği iktisadi büyümeyi sağlayamamış olduğu, dolayısıyla "serbest ticaret herkesin yararınadır" önermesinin doğru olmadığ sonucuna ulaşmaktadır. Zira, 1960-1980 arasında ülkelerde GSYİH yılda yüzde 3.1 oranında artmışken, 1980-2000 arasında yılda sadece yüzde 1.4 oranında artmıştır. Buna göre, genel olarak ülkeler, özellikle de kalkınmakta olan ülkeler "yanlış", yani korumacı politikalar uyguladıkları 1960-1980 döneminde, "doğru", yani neo-liberal politikalar uyguladıkları 1980-2000 döneminden daha fazla büyümüşlerdir.

Öte yandan yazar, kalkınmaya yönelik kurumsal gelişme açısından ise, iyi yönetişim paketi şeklinde bugün kalkınmakta olan ülkelere tavsiye edilen kurumların çoğunun aslında BKÜ'lerde iktisadi kalkınmanın nedeni olmaktan çok sonucu olduğu sonucuna ulaşmaktadır. Dolayısıyla, ne kadarının bugünün kalkınmakta olan ülkeleri için gerçekten gerekli olduğunun açık olmadığını belirtmektedir. Yazara göre, çoğunlukla Anglo-Amerikan kurumlarından oluşan bir dizi kurumun herkes tarafından benimsenmesi gerektiğini öne süren bugünkü egemen görüş son derece problemlidir. Öte yandan, günümüz kalkınmakta olan ülkelerin kurumsal gelişmeleri, BKÜ’lerin kalkınma aşamalarındayken mevcut kurumsal gelişmelerinden bir hayli ileridedir (s, 214, 215).

Kalkınma Reçetelerinin Gerçek Yüzü, BKÜ'ler ve uluslararası örgütler aracılığıyla şekillendirilen yeni dünya düzeni hakkında belirli bir bakış açısı sunmaktadır. Kitapta, politikalar ve kurumsal gelişme anlamında, BKÜ'lerin kalkınma aşamalarında korumacılığı, kalkınma aşamaları sonunda ise serbestleşmeyi benimsedikleri farklı verilerle gösterilmektedir. Yazar, BKÜ'lerin günümüzde neo-liberal politikaları benimsediğini, bunu kalkınmakta olan ülkelere de dayatmakla kendi tarihsel deneyimleriyle çeliştiklerini söylerken haklıdır. Ancak yazar, bunun nedenleri üzerinde durmamaktadır. Diğer bir ifadeyle, neo-liberal politikaların neden egemen paradigma haline getirilmeye çalışıldığı yazar tarafından açıklanmamaktadır. Böyle olduğunda ise, kapitalizmin eleştirisi eksik kalmaktadır.

Bu anlamda, 1970'lerde kapitalizmin yapısal bir krizle karşı karşıya kalındığı, neo-liberal politikaların BKÜ’ler ve uluslararası örgütlerlerce krizden çıkışta önemli bir rol oynaması amaciyla uygulamaya sokulduğu belirtilmeden, bu politikaların kalkınmakta olan ülkelere dayatılmasının yanlış olduğunu söylemek bir noktaya kadar açıklayıcı olabilmektedir. Ancak bu politikaların 
kapitalizmin yeniden yapılanmasının bir parçası olduğunu açıklamakta yetersiz kalmaktadır.

Yazar, bu türden bir ilişkiyi kurmaktan çok, günümüzde korumacı politikaların kalkınmakta olan ülkelerce uygulanmasının (BKÜ'ler ve uluslararası örgütlerce) önüne geçilmesini birincil problem olarak gösterme çabasındadır. Birincil problem buysa şayet ve kapitalizmle ilgili bir sorun yoksa o zaman mücadele, bu ülkelerin korumacı politikaları uygulamaları yönünde serbest kalınmaları gerekliliği üzerine kurulabilir. Nitekim yazar, bir politika olarak kitabında bunu önermektedir. Yazar, "Öyleyse ne yapılmalı?” sorusuna cevap olarak, uluslararası örgütlerin neden var olduklarını ve kalkınmakta olan ülkelere politika ve kurumsal gelişmede neden neo-liberal politikaları dayattıklarını ayrıntılı olarak sorgulamak yerine, kalkınmakta olan ülkelere korumacı politikaları uygulamamaları yönünde baskıda bulunmamalarını, bunu siyasi ve mali desteğin bir koşulu olarak sunmamaları gerektiğini söylemektedir. Yine uluslararası serbest ticaretin hukuki çerçevesini çizen DTÖ kuralları ve anlaşmalarının neden var olduklarını tartışmak yerine, bu kuralların ve anlaşmaların bebek sanayilerin desteklenmesine yönelik araçların aktif kullanımına imkân verecek şekilde yeniden yazılmaları gerektiğini belirtmektedir.

Bu kitabında kalkınmakta olan ülkeler için neo-liberal politikaların alternatifi olabilecek politikalar üzerinde sınırlı duran yazar, bu eksikliği Ilene Grabel ile yayınladığ1 Kalkınma Yeniden: Alternatif İktisat Politikaları Elkitabı çalışmasıyla gidermektedir.

Kalkınma Yeniden: Alternatif İktisat Politikaları Elkitabı iki bölümden oluşmaktadır. Birinci Bölüm, Kalkınma Reçetelerinin Gerçek Yüzü kitabının genel bir özetini sunuyor denilebilir. Bu bölümde, "Kalkınmaya İlişkin Söylenceler ve Gerçekler" başlığı altında, "başka seçenek yok" sloganıyla evrenselleştirilmeye çalışılan neo-liberal politikalara özgü altı söylenceye (mit'e) yer verilmekte bunlar eleştirilmektedir. Bir önceki kitapta anlatılanların tekrarı olacağından, bu bölümün üzerinde durulmayacaktır. Bununla birlikte, kitabın özünü İkinci Bölüm oluşturmaktadır ve bir önceki kitabın devamı niteliğindedir. $\mathrm{Bu}$ bölümde, kalkınmakta olan ülkeler için neo-liberal politikaların uygulanabilir alternatifleri ayrıntılı olarak anlatılmaktadır. $\mathrm{Bu}$ politikalar sırasıyla, "dış ticaret ve sanayi”, "özelleştirme ve fikri mülkiyet hakları", "uluslararası özel sermaye hareketleri”, "yurtiçi finansal denetim" ve "makro ekonomik politikalar ve kurumlar" başlıkları altında açıklanmaktadır.

Politika seçenekleri 1-Dış Ticaret ve Sanayi: Bu başlık altında dış ticaret ve sanayi konularındaki alternatif politika önerileri açıklanmaktadır. Yazarlar ilk olarak, neo-liberalizmin "en iyi dış ticaret politikası serbest dış ticarettir" 
görüşüne karş1lık olarak, kalkınmış ülkelerin kalkınmasının serbest dış ticaret yoluyla olmadığ 1 görüşüyle itiraz etmektedirler. Onlara göre, günümüzün BKÜ'lerinin kalkınması serbest dış ticaret yoluyla olmamıştır. Dolayısıyla, neo-liberal politika önerilerinde altı çizilen serbest dış ticaretin yerine gümrük vergileri, kotalar ve yerli şirketlere verilen sübvansiyonlar gibi korumacı politikalar kalkınmakta olan ülkelerde endüstriyel gelişme için önemlidir. Nitekim II. Dünya Savaşı sonrasındaki dönemde Kore, Tayvan, Brezilya, Çin ve Hindistan bu türden etkili stratejik ticaret politikaları uygulayarak büyük yararlar elde etmişlerdir (s, 79-112).

Sanayi politikası açısından ise yazarlar, kalkınmakta olan ülkelerde öncelikli olarak bebek sanayilerin korunduğu sağlam bir temel üzerine girişken bir ihracat stratejisinin desteğiyle geniş bir sanayi tabanının oluşturulması gerektiğini söylemektedirler. Bu kapsamda, eğitim, altyapı, kamu yatırımı ve teknoloji politikası yanında ihracatta, yerli ara malı kullanımında, AR-GE kapasitesinde ve rekabet edebilme gücünde artışlar sağlayacak hedefler belirlenmelidir.

Politika seçenekleri 2-Özelleştirme ve Fikri Mülkiyet Hakları: Bu başlık altında özelleştirme ve fikri mülkiyet konularındaki alternatif politika önerileri açıklanmaktadır. Yazarlara göre, kalkınmakta olan pek çok devlet kısa veya orta vadeli bütçe sıkıntılarının üzerine gittiklerini göstermek amacıyla özelleştirmeye girişmiştir. Ancak onlara göre bunun yolu, büyük kamu iktisadi teşebbüslerini (KITT) özelleştirmek değildir. Bütçe açıkları mali reform yoluyla daha kolay giderilebilir. Diğer taraftan özelleştirmenin maliyetleri de hesaba katılmalıdır. Örneğin, korumasız toplumsal gruplar açısından özelleştirmenin gelir dağılımıyla ilintili, siyasi ve toplumsal maliyetleri vardır. Bundan dolayı, özeleştirme yerine KİT'lerin performansını artırma yoluna gidilmelidir. $\mathrm{Bu}$ kapsamda KìT'lerin yükümlülükleri belirlenmeli ve hesap sorulabilir bir yapıya kavuşturulmaları gerekir. Ayrıca bilgi sistemleri ve performans sistemi geliştirilmeli, gözetim sistemi geliştirilmeli, yöneticilerin ve çalışanların etkinliği, üretkenliği artırılmalıdır

Bu başlık altında ele alınan fikri mülkiyet hakları (FMH) son yılların tartışmalı konularından birisidir. Günümüzde fikri mülkiyet hakları DTÖ kapsamında yer alan TRIPS $^{6}$ ile hukuksal çerçeveye oturtulmuştur. Yazarlar açısından neoliberal görüşe göre, FMH'ler BKÜ'lerin gelişmesinde, yenilik üretmede ve yatırım yapmada çok önemli bir yere sahiptir. Bu bağlamda, FMH'ler kalkınmakta olan ülkelerin de yararına olacaktır. Zira FMH'lerin bu ülkelerde korunması teknolojik yenilikleri ve yabancı yatırımları teşvik etmekte, ileri

6 Trade-Related Intellectual Property Rights - Ticaretle İlişkili Fikri Mülkiyet Hakları 
teknolojilere ve yeni ürünlere ulaşılabilmesini kolaylaştırmakta, çok uluslu şirketler (ÇUŞ) bu ülkelerin ihtiyaçlarına yönelik yeni ürünler ve teknolojiler geliştirmeye daha istekli olmaktadırlar.

Ancak yazarlara göre, FMH'ler BKÜ'lerin gelişmesinde önemli bir katkısı sağlamamıştır. Onlara göre, tarihsel kaynaklar, BKÜ’lerin sanayileşme süreci tamamlanana kadar patent haklarını tanımadığını ve uygulamadığını ortaya koymaktadır. Yazarlar açısından günümüzde kalkınmakta olan ülkelerde fikri mülkiyet haklarını korumanın sağlayacağı ekonomik yararlar az sayıdadır. Üstelik FMH'ler (ÇUŞ'lara lisans hakk1 olarak yüklü ödemeler yapma zorunluluğu olduğundan) bu ülkeler için pahalıya mal olmaktadır. Dolayısıyla, kalkınmakta olan ülkelerin iktisadi çıkarlarıyla bağdaşan uygulama, FMH'leri gevşek bir koruma altında tutmaktır. Diğer taraftan, teknolojik yenilikleri özendirip geliştirmek için hedeflenen uygulamalı araştırmalara yönelik eğitim ve devlet desteği vermek çok daha önemlidir. Yazarlar, bu bölümde, fikirlerin kamusal mülkiyeti konusuna değinerek ilgi çekici bir tartışma da yapmaktadırlar. ${ }^{7}$ (s, 113-140).

Politika seçenekleri 3-Uluslararası Sermaye Hareketleri: Bu başlık altında uluslararas1 sermaye hareketleri konusunda alternatif politika önerileri açıklanmaktadır. Burada, öncelikli olarak uluslararası sermaye hareketlerinin kamuya ait ve özel sermaye hareketlerinden oluştuğu belirtilmektedir. Buna göre, kamuya ait sermaye hareketleri devletler arasında sermaye transferi yoluyla olurken, özel sermaye hareketleri banka kredisi, portföy yatırmı ve doğrudan yabancı yatırımı yoluyla gerçekleşmektedir. ${ }^{8}$

Yazarlara göre, kalkınmakta olan ülkelere akan uluslararası sermayenin bileşimi 1990'larda değişmiştir. Geçmişte bu ülkelere akan başlıca öze sermaye

7 Bu konu hakkında daha ayrıntılı bilgiler için güncel bir kaynağa bakılabilir: Karlıdağ K. Serpil (2010), Fikirlerimizin Sahibi Kim? Türkiye'de Müzik Endüstrisinde Telif Hakları Politikaları, (İstanbul: Kalkedon Yayınları, 1. Baskı).

8 Yazarlara göre, devletler arasında sermaye transferi tek taraflı veya çok taraflı hareketler biçiminde gerçekleşir. Bir devletin diğerine kredi vb. yoluyla sermaye aktarması tek taraflı hareketlere örnektir. IMF, Dünya Bankası gibi çok taraflı kuruluşların benzer bir yolla sermaye aktarması ise çok taraflı hareketlere örnektir. Özel sermaye hareketleri ise, ticari bankaların veya uluslararası örgütlerin bir ülkede kamu sektörüne veya özel sektöre verdiği kredi (banka kredisi), yatırımcının yerleşik olmadığı bir ülkede devletin veya özel sektörün piyasaya sürdügü tahvilleri, türevleri ve diğer finansal araçları satın alması (portföy yatırmı) ve yatırımcının yerleşik olduğu ülke dışındaki bir ülkede bir şirketten denetim hissesi satın alması-ki bu, yatırımcının yeni bir tesis kurması ya da mevcut firmaların varlıklarının satın alınması şeklinde olabilir (doğrudan yabancı yatırımı) yoluyla gerçekleşebilmektedir. 
yabancı bankaların verdiği kredilerken, 1990'larda doğrudan yabancı yatırımı (DYY) ve portföy yatırımı (PT) bu kredilerin yerini almıştır. Kitapta verilen nicel veriler bu değişimi ortaya koymaktadır. Buna göre, 1980'de 65,3 milyar dolar olan yabancı banka kredileri 2000 yılına gelindiğinde 5,1 milyar dolara gerilemiştir. Diğer taraftan, 1980'de sırasıyla 4,4 milyar dolar ve sıfır olan DYY ve PT 2000 y1lına gelindiğinde 160,6 milyar dolara ve 26 milyar olara yükselmiştir. Ancak bu veriler, kalkınmakta olan ülkelere akan yabancı özel sermayenin toplamda yüzde 5,5 olduğu gerçeğini de ortaya koymaktadır. $\mathrm{Bu}$ bağlamda, sermaye hareketlerinin dağılımının eşitsiz ve kalkınmakta olan ülkelerin dünya sermaye akımlarındaki payının çok az olduğu söylenebilir.

Yazarlar açısından neo-liberal görüşe göre kalkınmakta olan ülkelerde sermaye akımlarının serbestleștirilmesinin sayısız ekonomik yararı vardır. Özellikle yatırım, gelir ve ekonomik büyüme bağlamında başarı sağlamanın yolu sermaye akımının serbestleștirilmesidir. Ancak yazarlara göre sermaye hareketlerinin serbest olması, çok sayıda ağır, genel sorunlara neden olmaktadır. Kitapta bu konuda özerinde ayrıntılı olarak durulmaktadır. Öne çıkanlar şunlardır.

Döviz kurlarının piyasada belirlendiği kur sisteminde, büyük ani sermaye girişleri yerli paranın değer kazanmasına neden olabilmektedir. Ancak bu durum, ithalatın artmasını, ihracatın ise azalmasını beraberinde getirir. Zira, ithal mallar yerli tüketici açısından ucuzlar, ihraç malları yabancı tüketici açısından daha pahalı hale gelir, bu da ödemeler dengesinde sorunlara yol açar. Özel sermaye girişleri, yerli ve yabancı yatırımcıların yurtiçi politikaların uygulanmasında uygunsuz biçimde karışması olasılığını artırır. Özel sermaye girişleri aynı zamanda yurtiçi kaynakların yabancı denetimi/mülkiyeti altına girmesi sorununu gündeme getirir. Diğer taraftan, sermaye girişleri sermaye çıkışlarını da beraberinde getirir ki, bu durum, örneğin ani büyük sermaye çıkışlarında yerli paranın değer kaybetmesine neden olur. Herhangi bir güvensizlik ortamında sermaye kaçışı finansal istikrarsızlığa, bazen de finansal krize yol açabilir.

Yazarların sermaye serbestliğinin neden olabildiği tüm bu olumsuzluklara karşı getirdikleri alternatif politika önerisi sermaye denetimidir. Yazarlar, yabancı ve yerli sermaye akımlarının çeşitli türleri üzerinde uygulanan iyi tasarımlanmış denetimlerin önemli amaçlara ulaşmayı sağlayabileceğini göstermek için aralarında kalkınmış ülkelerin geçmişte uyguladıkları kapsamlı sermaye denetimleri uygulamaları da olmak üzere, çok sayıda ülke örneğinden kanıtlar sunmaktadırlar. Çin örneğinde olduğu gibi ekonomik açıdan başarılı ülkelerin uyguladıkları denetimlerin finansal istikrarı sağlayabildiği, cazip yatırım türlerini ve finansal düzenlemeleri teşvik edebildiği, spekülatörlerin ve çeşitli 
dış odakların karar alma sürecine karışmasını ve/veya ulusal kaynaklar üzerinde söz sahibi olmasını engelleyebildiği belirtilmektedir (s, 141-192).

Politika seçenekleri 4-Yurtiçi Finansal Denetim: Bu başlık altında yurtiçi finansal denetim konusunda alternatif politika önerileri açıklanmaktadır. Neoliberal görüş açısından olumlanan finansal serbestleştirme konusuna değinen yazarlar, bu türden bir serbestleşmenin genellikle spekülasyona dayanan gelişmeye yol açtığını ve bunun hemen her zaman para ve bankacılık krizleriyle sonuçlandığına dikkati çekmektedirler. Onlara göre finansal serbestleştirme aynı zamanda gelir eşitsizliğini, siyasi ve ekonomik güç farklılıklarını ve finansal kırılganlığı artırabilmektedir. Bu kapsamda yazarlar açısından alternatif politika önerisi, yurt içi finansal serbestleştirme sınırlı ve ancak yararlı sonuçlar elde etmenin kesin olduğu ve bu sonuçlara başka yollarla ulaşmanın mümkün olmadığı durumlarda benimsenmelidir (s, 193209).

Politika seçenekleri 5-Makroekonomik Politikalar ve Kurumlar: son olarak bu başlık altında makroekonomik politikalar ve kurumlar konularındaki alternatif politika önerileri açıklanmaktadır. Bunlar, "döviz kuru ve döviz politikaları", "merkez bankacılığı" ve "para politikaları ve maliye politikası"dır.

İlk olarak, döviz kuru ve döviz politikaları açısından bakıldığında, yazarlara göre kısıtsız konvertibilite yerli paranın değer kaybetmesi, parasal sistemin çökmesi, sermaye kaçışları ve finansal istikrarsılılk olasılıklarını güçlendirmektedir. Bu nedenle dalgalı döviz kuru rejimlerinde sik sik rastlanan ani ve büyük kur değişiklikleri kalkınmakta olan ülkelere çok pahalıya mal olmaktadır ve kalkınmakta olan ülkelerin çoğu, dalgalı döviz kurunun yol açtığı parasal istikrarsızlığa katlanabilecek kadar güçlü değildir. Yazarlara göre, kontrollü döviz kuru rejimleri birçok ülkenin kalkınma sürecinde önemli bir rol oynamıştır. 1990'ların başında Güney Kore, Malezya, Endonezya ve Şili'deki uygulamalar ve kalkınma buna örnektir. Dahası, II. Dünya savaşı sonrasında ortaya çıkan ekonomik zorluklar karşısında kalkınmış ülkeler de bu uygulamaya geçmişlerdir. $\mathrm{Bu}$ açıdan yazarlara göre, konvertibiliteyi denetlemek, sabit kurları değişen ekonomik koşullara göre ayarlayabilen mekanizmalar kurmak alternatif politikalar olarak uygulanmalıdır.

Merkez bankları açısından bakıldığında da yazarlar açısından neo-liberal görüş, merkez bankalarının asli görevi olan para politikasını ancak bağımsız bir yapıya kavuştuklarında yerine getirebileceğini ileri sürmektedir. Nitekim IMF, yapısal uyum programlarıyla kalkınmakta olan ülkelere finansal ve teknik 
yardımın koşullarından biri olarak merkez bankası reformunu göstermektedir. ${ }^{9}$ Yazarlar, bağımsız merkez banklarının yapısal olarak çıkarları düşük enflasyonla örtüşen finans camiasının yararına işleyeceğine dikkati çekerek topluma içkin, siyasi makamların hesap sorabildiği merkez bankalarının olması gerektiğini savunmaktadırlar. Onlara göre bu türden bir yapıya sahip merkez bankaları, asli görevlerini daha iyi yerine getirme yanında, kalkınmakta olan ülkelerde kalkınma hedeflerine ulaşmak için önemli bir rol de oynayabilmektedir.

Maliye politikası açısından ise yazarlara göre neo-liberal görüş, aşırı harcamayı sorunun ana kaynağı olarak görmekte ve bu açıdan kalkınmakta olan ülkelere aşırı harcama sorunlarını çözmek için mali disiplin uygulamasını tavsiye etmektedir. Nitekim maliye politikası da IMF tarafindan yapılması istenen reformların bir unsuru olarak öne çıkarılmaktadır. Yazarlara göre, maliye politikasın bir aracı olarak, kalkınmakta olan ülkelerde harcamaları kısma yöntemi, sosyal program harcamaları örneğinde olduğu gibi, yaşam standartlarını düşürebilmekte, acil ve uzun vadeli ekonomik faaliyetleri tehlikeye sokabilmektedir. Çözüm, ekonomik büyümeyi ve yatırımları teşvik etmek ve büyük sosyal sıkıntıları hafifletmek için stratejik, iyi tasarımlanmış ve doğru yönlendirilen kamu harcama programlarının hayata geçirilmesidir. Diğer taraftan, kamu harcamalarını artırmanın koşulu, yeni vergi gelirleri elde etmek ve vergi kaçakçılığını azaltmak olmalıdır (s, 211-254).

Kalkınma Reçetelerinin Gerçek Yüzü kitabı için yukarıda dile getirilen eksikliğin Kalkınma Yeniden: Alternatif Iktisat Politikaları Elkitabı için de geçerli olduğunu söyleyebiliriz. Yazarlar, neo-liberal iktisat politikalarına alternatif politikalar geliştirdiklerini söylemektedirler ancak, bu politikaların daha geniş bir perspektiften kapitalist küresel ekonomiye alternatif politikalar olduğunu söylememektedirler. Bu bağlamda, alternatif oldukları iddiasındaki politikaların var olan kapitalist sistem içinde sunulması, bunların ne derece antikapitalist oldukları hakkında şüphe uyandırmaktadır. Bununla birlikte, çağımıza egemen olan ve yaşam pratiklerimiz üzerinde derin izler bırakan neoliberal politikaların alternatifi olabileceğini her iki kitap aracılığıyla okumak ve üzerine düşünmek anlamlı ve umut vericidir.

Kalkınma Yeniden: Alternatif İktisat Politikaları Elkitabı'nda okumay1 kolaylaştıran bir yazım tekniği kullanılmaktadır. Kitabın Birinci Bölümü’nde, her bir konu için öncelikle neo-liberal görüş açıklanmakta, ardından söz konusu konuya ilişkin neo-liberal görüş irdelenmekte, sonrasında neo-liberal görüşün reddine gidilmektedir. İkinci bölümde bu sıralamaya neo-liberal politikaya

92001 krizi sonrasında Türkiye’yi kurtarma programlarında bu koşul yer almaktaydı. 
290 • Ankara Üniversitesi SBF Dergisi • 65-3

alternatif politikalar eklenmektedir. Kitap ayrıca okuyucuya zengin bir kaynakça ve (neo-liberal ve alternatif politikaları anlatan) ek okuma listesi sunmaktadir.

\section{Kaynaklar}

David, Harvey (2008), Yeni Emperyalizm (İstanbul: Everest Yayınları, 2. Bask1) (Çev.: Hür Güldü).

Saad-Filho, Alfredo (2007), Kapitalizme Reddiye (İstanbul: Yordam Yayınları,) (Çev.: Emel Kahraman).

Zafer KIYAN, Ankara Üniversitesi, İletişim Fakültesi, Araştırma Görevlisi. 